Click www.researchjournal.co.in/online/subdetail.html to purchase.

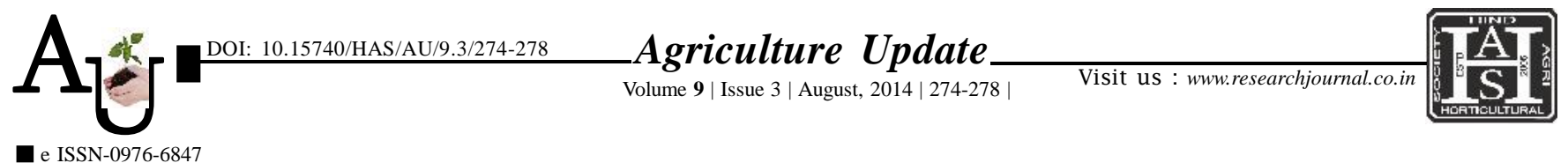

\title{
Research Article Constraints faced by farmers during storage of food grains
}

\author{
NAGESH, S.V. HALAKATTI AND S.N. HANCHINAL
}

Article Chronicle : Summary : Storage is an important post-harvest function which involves holding and preserving of agricultural

Received :

17.01.2013;

Revised :

15.05.2014;

Accepted :

01.06.2014

KeY Words:

Food grains, Storage

quantity, Storage

duration, Problems,

Suggestions commodities from the time they are produced until they are needed for consumption. Farmers store different quantity of food grains for different durations and in this storage period they face many problems due to various factors. An attempt has been made to document various problems faced by farmers during storage of food grains and their suggestions for better storage of food grains. The study was conducted in Dharwad taluk of Dharwad district of Karnataka state. The study revealed that most of the farmers store all the food grains like jowar, paddy, wheat etc., in the range of 1-10 quintals. About 50 per cent (47.5\%) of respondents felt that lack of proper storage space is major problem faced by farmers. Arrangements for the training on improved methods of food grain storage $(30.00 \%)$ and disseminating information on insecticides and fumigants (22.55) were the suggestions given by the respondents.

How to cite this article : Nagesh, Halakatti, S.V. and Hanchinal, S.N. (2014). Constraints faced by farmers during storage of food grains. Agric. Update, 9(3): 274-278.
Author for correspondence :

S.V. HALAKATTI Department of Agricultural Extension Education, College of Agriculture, University of Agricultural Sciences, DHARWAD (KARNATAKA) INDIA Email: sunilvhalakatti@ rediffmail.com, sunilhalakatti@gmail.com See end of the article for authors' affiliations 